\title{
Factors Influence Brand Awareness Towards Purchasing Intention on Susu Kental Manis Frisian Flag
}

\author{
Herliani Gemmy $^{1}$, Jony Oktavian Haryanto ${ }^{2 *}$, Neva Permatasari Sutedjo ${ }^{3}$ \\ ${ }^{1,2,3}$ President University, Bekasi 17550, Indonesia
}

\begin{abstract}
A B S T R A C T
Frisian Flag as a market leader dairy product in Indonesia has a large market share. However last year, brand value of Susu Kental Manis Frisian Flag has decreased dramatically. In addition, this study aimed to determine the factors that influenced brand awareness towards purchasing attention on Susu Kental Manis Frisian Flag. The type of this research was survey research by using questionnaire and took 200 respondents who knew and have tried Susu Kental Manis Frisian Flag. The data processing used structural equation modelling, this research result showed that positive factors which influenced brand awareness were attractiveness of advertisement and distribution intensity. While, brand awareness affects actual purchasing intention positively.
\end{abstract}

ARTICLE INFO

Keywords:

Brand Awareness,

Purchasing Intention,

Structural Equation Modeling.
*Corresponding Author E-mail: jonyharyanto@yahoo.com

Copyright $\Subset 2019$ Authors. This is an open access article distributed under the Creative Commons Attribution License, which permits unrestricted use, distribution, and reproduction in any medium, provided the original work is properly cited.

\section{INTRODUCTION}

In current era of globalization, companies are required to be able to create a product which can compete with other products if they want to survive in the flow of business competition. The number of new competitors that have sprung up with new marketing strategies will also make competition tighter and heavier. A company $\mathrm{c}$ an be a winner in its business competition if the company is able to attract as many customers as possible.

Indonesia's huge population has become a very potential market for companies to market their products. Domestic companies and foreign companies try to set up business ventures and create types of products that will be favored by prospective customers. Competition for prospective customers by each company will be even more intense and tighter. Buying interest is obtained from a learning process and thought processes that form a perception (Sheilla, 2017).

The purchase interest creates a motivation that continues to be recorded in the minds of consumers and becomes a very strong desire, then in the end when a consumer must fulfill his needs according to what is in his mind. The effect of buying interest hierarchy is used to describe the order of the process of the emergence 
of beliefs. Attitudes and behavior are the stages of information processing. Confidence shows cognitive knowledge possessed by consumers by associating attributes, benefits and objects (by evaluating information), while attitudes refer to feelings or effective responses (Muharam, 2011).

Brand is a company's most important asset. Only companies that have strong brands can survive amid the onslaught of competitors. A strong brand makes the product of a company stand out even though thousands of similar products are scrambling for mutual attention. The company develops strategies regarding their items in its product line by making a number of decisions regarding product attributes, press, packaging, labeling, and product support services. The product attribute decisions here include the quality, features, style, and design that the company wants to offer (Elyardi, 2014). One of the big companies in Indonesia that has a strong, well-known brand is PT. Friesche Vlag Indonesia

PT. Friesche Vlag Indonesia show its ability to produce quality products. PT. Friesche Vlag Indonesia and PT. Foremost Indonesia produces various brands of milk and the most popular is Frisian Flag Milk. Frisian Flag milk consists of milk powder, ready-to-drink liquid milk, and sweetened condensed milk as its flagship product. These products consist of various sizes and shapes of packaging designed according to consumer needs.

Based on Tribun Jabarid (2018), sweetened condensed milk has been known for years by the public as a product containing natural milk and become the favorite milk product of Indonesian society. Therefore, sweetened condensed milk gets the highest sales compared to other dairy products. In a review conducted by Marketeers.com (2016) one of the causes of the high sales of sweetened condensed milk is that it is easy to distribute in all regions of Indonesia. In addition, the expiration period is relatively long and the price is more affordable.

High milk demand in recent years has made milk producers race to boost sales growth. PT. Friesche Vlag Indonesia, as the market leader of the largest milk producer in Indonesia needs to take an action that is used as a strategy to maintain the national milk market share, in this case sweetened condensed milk products.

As the market leader of milk producers in Indonesia, PT. Friesche Vlag Indonesia has a large market share. This makes the company's brand value higher than its competitors, such as Indomilk and Cap Enak. But in the past two years, the brand value of Frisian Flag sweetened condensed milk has decreased. The following is the data index of brand value of milk producing companies in the category of sweetened condensed milk in Indonesia based on research conducted by Top Brand Award:

Table 1. Indonesia Top Brand Award 2017 \& 2018 Category of Sweetened Condensed Milk

\begin{tabular}{|l|c|c|l|c|c|}
\hline \multicolumn{3}{|c|}{2017} & \multicolumn{3}{c|}{$\mathbf{2 0 1 8}$} \\
\hline Brand & TBI & TOP & Brand & TBI & TOP \\
\hline Frisian Flag & $66.1 \%$ & TOP & Frisian Flag & $40.3 \%$ & TOP \\
\hline Indomilk & $24.8 \%$ & TOP & Indomilk & $27.3 \%$ & TOP \\
\hline Cap Enaak & $3.7 \%$ & TOP & Cap Enaak & $19.7 \%$ & TOP \\
\hline
\end{tabular}

Source: Top Brand Index 2017 \& 2018;

Category Food and Beverages

Based on Table 1, it shows that the brand performance of Frisian Flag sweetened condensed milk has decreased. This can be seen from the Top Brand Index (TBI) of Frisian Flag sweetened condensed milk which has decreased from 2017 to 2018. Top Brand Index is formulated based on 3 variables: Mind Share, Market Share and Commitment Share. The first variable, Mind Share, indicates abrand's strength inside the minds of the consumers of the respective product category.

The formulation of the problem in this study was what factors that influence consumer's perception towards the sweetened condensed milk product from Frisian Flag brand to answer the problem of this study "What kind of factors that influence the awareness and interest of customers to buy sweetened condensed milk Frisian Flag". 
Furthermore, to answer the research problem, the following research questions will be used:

1. Does product packaging positively influence brand awareness?

2. Does the attractiveness of advertising positively influence brand awareness?

3. Does distribution intensity of product positively influence brand awareness?

4. Does brand awareness positively influence purchasing intention?

\section{LITERATURE REVIEW}

\section{Product Packaging}

According to Resmi (2015), packaging is an attribute related to the product but it is not part of the physical product it self. The attributes describe the characteristics of a product or service. Attributes consist of attributes related to products which are related to physical composition or services needed and attributes not related to products attributes which are not involved in product formation physically for service.

Based on Muharam (2011) research explained that consumers become interested in a product if the consumer has evaluated the product in question. Consumers see an attractive product can be caused by features or attributes offered, make comparisons with competitors' products, the reputation of the company that makes the products, and technology used in making these products.

In general, packaging functions are: (1) Protecting and preserving products such as protect from ultraviolet rays, heat, air humidity, oxygen, collisions, contamination from dirt and microbes that can damage and reduce product quality, (2) As a product identity, in this case packaging can be used as a communication and information tool to consumers through labels that are available on the packaging, (3) Increase efficiency, such as: making it easier to calculate, facilitate shipping and storage (Purnamasari, 2014).

Muharam (2011) stated that consumers rarely read in detail the label of a product, both price and table of contents in buying a product. This happens because of the decision making in a short time. Packaging design that has a unique and pleasing to the eye will be interesting to buy.

Based on the explanations above, it can be concluded that product packaging will create memory especially in the brand awareness of the product that will be embedded in the minds of consumers forever. Packaging design can be in the form of logos, symbols, or writing that will encourage consumers to remember the product. Attractive and easy to remember designs will add value to a product in the eyes of consumers. So that consumers already have their own choice if you want to buy a product.

Based on the results of previous research conducted by Hufron (2015) that the product packaging variable has a positive effect on brand awareness. Other research conducted by Qurohman (2016) shows that there are positive influences and significance effect of product packaging toward brand awareness. Therefore, the hypothesis that appears is:

$\mathbf{H}_{1}$ : Product Packaging positively influence Brand Awareness

\section{The Attractiveness of Advertising}

Advertising is one component of marketing mix that is generally done by company. According to Darma (2014), advertising is the use of paid media by a seller to communicate persuasive information about products (ideas, goods, services) or organizations as a strong promotional tool. Advertising has various forms (industry, consumers, brands, products, local and so on) designed to achieve various objectives (instant sales, brand recognition, preferences and so on).

The form of response from consumers that is expected by companies is consumers buy the products. Consumers will evaluate the product or brand based on the information they have. The company can influence consumers by providing information in several ways such as advertising. How much influence will depend on the ability of 
the information to build perceptions, beliefs and attitudes of the consumer on a product (Sofian, 2011).

Based on Rusli (2013), advertising can interact with product experience in influencing the way consumers evaluate products. Furthermore, advertising can increase consumer preferences that are formed after using the product and conversely the experience of using products can make consumers more responsive to advertising.

Supriono (2017) stated that there are several advertising elements that must be considered in TV advertising as follows:

1. Jingle is music contained in advertisements, can be songs or only music illustration as background.

2. Storyboard is a visualization for television ads that are series of images which shows the ad storyline.

3. Script is the arrangement of a sentence that forms a headline or main message in an ad.

4. Endorser is a supporting figure who can be used as an advertising exhibition that aims to strengthen the message conveyed.

5. Slogan or closing line (the pay of line). Slogan can be displayed only in voice, visual (writing / drawing) only on radio and visual (writing, drawing and sound).

6. The logo is used so that the public can easily know and recognize the product, company or anyone who displays the ad.

Through the above explanation it can be concluded that, advertising is an effective marketing communication strategy in its role in marketing a product. Advertising helps consumers in choosing the products they will use. In addition, advertisements that are attractive and have high originality, provide a distinctive experience and impression in the minds of consumers about the usefulness of the advertised product. They already have their own judgments and perceptions when using a product. With the existence of advertisements, consumers by themselves already have a choice in their minds to buy or use the brand that is in the ad.
Based on the results of previous research conducted by Subekti (2010) the attractiveness of advertising has a positive effect on brand attitudes. More and more high attractiveness of the advertisement, the higher the attitude towards the brand of a product. Other research conducted by Muharam (2011) conclude that the attractiveness variable of advertising has a positive influence on brand awareness. Therefore, the hypothesis that appears is:

$\mathbf{H}_{2}$ : The attractiveness of advertisement positively influences Brand awareness

\section{Distribution Intensity}

According to Ryanto (2015), distribution can be interpreted as a marketing activity which strives facilitate the delivery of goods and services from producers to consumers, so that their use is in accordance with what is needed (type, amount, price, place, and when needed). Distribution is interdependent organizations included in the process make products or services available for use or consumption. They are lane devices followed by products or services after production, which culminate with the buyer and use by the end user (Wismiarsi, 2015).

Based on the above definitions, it can be concluded that distribution is an activity that facilitates the distribution of products or services from producers to consumers, so that the product or service can be consumed by consumers. Distribution is an activity company to make products available to target consumers. Channel distribution is a group of traders and corporate agents who combine between physical displacement and the name of a product to create usefulness for certain markets. From the definition above, the author concludes that distribution are activities for delivering goods carried out by an organization with the aim that the produced product can be accepted by good consumers through intermediaries or not. From the above definition, elements can be found important in the distribution channel (Resmi, 2015). 
Tjiptono (2015) stated that consumers will be more satisfied if a product is available in many stores because it will be easily found when consumers want it. The availability of products should encourage knowledge brand, so that an increase in the intensity of the distribution will have a positive effect in brand name recognition and brand awareness.

Based on the results of previous research conducted by Riyanto (2015) distribution has a positive and significant effect on brand awareness. This means that the better or broader distribution the company does, it can increase brand awareness that also affects the purchasing intensity. Other research conducted by Ratnawati (2011) that has been done it can be concluded that the intensity of distribution has a positive effect on consciousness brand can be accepted. Therefore, the hypothesis that appearsis:

$\mathbf{H}_{3}$ : Distribution intensity positively influence Brand Awareness

\section{Brand Awareness}

Brand awareness is the ability of a prospective buyer to recognize and recall a brand as part of a category certain products. Brand awareness requires ranging continuum from the uncertain feeling that a certain brand is known beforehand, so that consumers are sure that the product is the only one brand in a certain group (Sugiarto, 2011).

Sofia (2011) describes brand awareness as the most important element in the communication process and a standard procedure in each process. In the absence of brand awareness, no other communication effect arises. For a consumer who buys a product of a brand, first of all, they must be made to know the brand. Attitudes towards brands cannot be formed, and interest in buying will not arise unless brand awareness already exists in their minds.

Maulana (2018) describe awareness brand as the most important element in the communication process and a standard procedure in each process. Without brand awareness, there is no effect other communication that appears. For a consumer who buys a product of a brand, first of all, they must be made to know the brand. The attitude towards the brand is not can be formed, and interest in buying will not arise unless brand awareness already in their minds.

According to Shimp (2013), brand awareness is the basic dimension in brand equity. Based on the perspective, a brand has no equity to consumers aware of the existence of the brand. Brand awareness shows the ability of a prospective buyer to recognize or recall that a brand is part of certain product categories (Durianto et al, 2013).

The strength of the existence of a brand in the customer's mind can be demonstrated by the ability of customers to know and remember a brand. The level of awareness of a brand by consumers range from the level of recognizing the brand that customers can recognize brands, to the extent that brands become dominant brand recalled, namely brands as the only one that is remembered and becomes the identity of the product category (Aaker, 2013).

Based on the results of previous research conducted by Yudhiartika (2012) it can be concluded that the brand variable awareness has a positive influence on buying interest variables. Therefore, the hypothesis that appears is:

$\mathbf{H}_{4}$ : Brand awareness positively influence purchasing intention

\section{Purchasing Intention}

Interest in buying is part of the component behavior in consuming. Consumer buying interest is the stage where consumers form their choices among several brands incorporated in the choice device, then finally did something purchase at an alternative that he likes the most or the process that goes through consumers to buy an item or service based on variety considerations (Pramono, 2012).

According to Yasin (2014) interest arising in the buyer's itself is often the opposite financial 
condition owned. Consumers buying interest are hidden desires in the minds of consumers. Interest in buying consumers always veiled in each individual self where no one can know what desired and expected consumers is.

Supriono (2017) argues that consumer purchasing intention is something that arises after receiving stimulation of the products he saw, the rise of the interest to try the product until finally the desire to buy the product so he can have it.

Muharam (2011) stated that there are four indicators of purchasing intention, they are: (1) Transactional asking is the tendency of someone to buy a product. (2) Refractive interest is the tendency of someone to refer products to others. (3) Preferential interests, namely interests that describe the behavior of someone who has the main preference for the product. (4) Explorative interest describes the behavior of someone who always searches for information about the product they are interested in and searches for information to support the positive nature of the product.
Based on the results of previous research conducted by Hufron (2015) the brand awareness variable has a positive effect on purchasing intention.

\section{Research Model}

Based on the literature review, a research model was formed which showed that the purchase intention was influenced by, Product Packaging, Attractiveness of Investment, Distribution Intensity and Brand awareness. Figure 1 below is the figure of the research model.

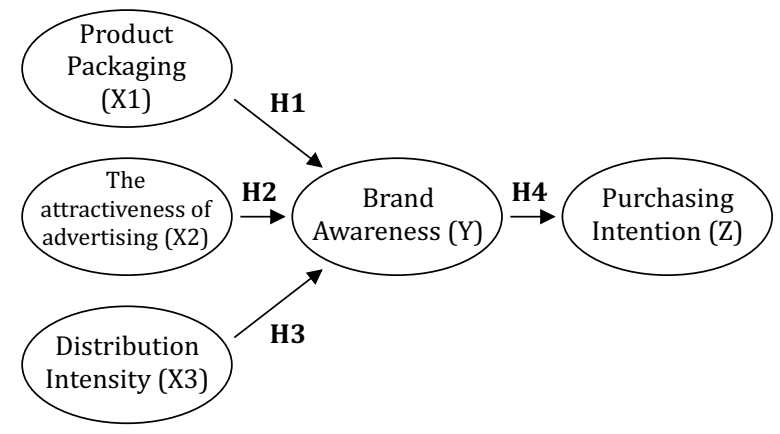

Figure 1. Research Model

\section{Variable Description}

Table 2. Observed Variables

\begin{tabular}{|c|c|c|c|}
\hline Variables & Definition & Indicators & Source \\
\hline $\begin{array}{c}\text { Product } \\
\text { Packaging }\end{array}$ & $\begin{array}{l}\text { Packaging is product container } \\
\text { which includes the physical } \\
\text { appearance of the product } \\
\text { (Resmi, 2015) }\end{array}$ & $\begin{array}{l}\text { 1. Unique packaging design. } \\
\text { 2. Packaging is easy to open. } \\
\text { 3. Packaging is easy to carry. } \\
\text { 4. Packaging is easy to use. } \\
\text { 5. Packaging variant designs. }\end{array}$ & $\begin{array}{l}\text { Resmi \& Wismiarsi } \\
\text { (2015) with modification }\end{array}$ \\
\hline $\begin{array}{c}\text { The } \\
\text { Attractiveness of } \\
\text { Advertisement }\end{array}$ & $\begin{array}{l}\text { The attractiveness of ad is the } \\
\text { delivery of messages about the } \\
\text { product with use several } \\
\text { approaches to attract consumers } \\
\text { (Hartono, 2016) }\end{array}$ & $\begin{array}{l}\text { 1.The uniqueness of ad storyboard. } \\
\text { 2. The uniqueness of ad jingle. } \\
\text { 3. The uniqueness of ad slogan. } \\
\text { 4. The uniqueness of ad message. } \\
\text { 5. The uniqueness of ad script. }\end{array}$ & $\begin{array}{l}\text { Kusumasari, \& Supriono, S } \\
\text { (2017) with modification }\end{array}$ \\
\hline $\begin{array}{l}\text { Distribution } \\
\text { Intensity }\end{array}$ & $\begin{array}{l}\text { Distribution intensity is } \\
\text { marketing activity which seeks to } \\
\text { facilitate the delivery of goods and } \\
\text { services from producers to } \\
\text { consumers (Ratnawati,2011) }\end{array}$ & $\begin{array}{l}\text { 1. Distribution place. } \\
\text { 2. Product availability. } \\
\text { 3. Channel Distribution. } \\
\text { 4. Completeness of product variance. } \\
\text { 5. Distribution range. }\end{array}$ & $\begin{array}{l}\text { Ratnawati (2011) } \\
\text { with modification }\end{array}$ \\
\hline $\begin{array}{c}\text { Brand } \\
\text { Awareness }\end{array}$ & $\begin{array}{l}\text { Brand awareness is the ability } \\
\text { of a prospective buyer to } \\
\text { recognize, recall a brand as part } \\
\text { of a category certain products } \\
\text { (Sugiarto, 2011) }\end{array}$ & $\begin{array}{l}\text { 1. Top of mind brand. } \\
\text { 2. Able to imagine the shape of } \\
\text { the product. } \\
\text { 3. Able to recognize the Brand from } \\
\text { the slogan. } \\
\text { 4. Brand knowledge. } \\
\text { 5. Able to Remember the brand logo. }\end{array}$ & $\begin{array}{l}\text { Muharam, A. \& Sofian, S. } \\
\text { (2011) with modification }\end{array}$ \\
\hline
\end{tabular}




\begin{tabular}{clll}
\hline $\begin{array}{l}\text { Purchasing } \\
\text { Intention }\end{array}$ & $\begin{array}{l}\text { Purchase intention is a decision- } \\
\text { making process carried out by }\end{array}$ & $\begin{array}{l}\text { 1.The desire to buy the product. } \\
\text { 2. Decide to buy the product }\end{array}$ & $\begin{array}{l}\text { Muharam, A. \& Sofian, S. } \\
\text { (2011) with modification }\end{array}$ \\
& $\begin{array}{l}\text { consumers before making } \\
\text { certain products needed by }\end{array}$ & 4. Become the first product to be & 4urchased. \\
consumers (Permana, 2014) & 5. Recommend the product to others.
\end{tabular}

\section{RESEARCH METHODS}

\section{Methods}

The population of the subjects of this study were people who knew and had consumed Frisian Flag sweetened condensed milk. From this population a sufficient number of samples were taken so that they could be studied to know the characteristics of the population as a whole. Samples will be taken in the amount of 200 from students, employees, and the general public. The sampling technique used was Convenience Sampling with consideration of convenience. In this study, the method used was the Structural Equation Modeling (SEM) technique. Some guidelines to determine the sample size for SEM are given as follows (Permana, 2014): (1) when estimating parameters using the Maximum Likelihood Estimation method, the recommended sample size is between 100 and 200, with a minimum sample of 50. (2) 5 to 10 times the number of parameters in the model. (3) Same as 5 to 10 times the number of manifest variables (indicators) of the entire latent variable.

\section{Survey Implementation}

The researcher conducted a survey by distributing questionnaires in the second week of November 2018 to the fourth week of November 2018. The questionnaire was distributed online. Distribution of online questionnaires was done through social media personal chat such as Facebook, Twitter and Instagram by using google spreadsheets to save time and facilitate data collection. From the distribution of the questionnaires and after passing the screening stage, the researcher managed to collect as many as 200 respondents. This number has fulfilled the minimum amount needed, which was 200 respondents.

\section{Measurement}

The tool used to collect primary data in this study was a questionnaire. The measurement scale was a five-point Likert Scale consisting of several question items. According to Permana (2014), Likert-type scale is a questionnaire design to check how strongly respondents agree or disagree with questions or statements in the questionnaire. The response format provided for these statements was strongly disagree (scale $=1$ ), disagree (scale $=2$ ), neutral (scale $=3$ ), agree $($ scale $=4)$ strongly agree $($ scale $=5)$.

\section{Pretest Study}

Table 3. Reliability and Validity Pre-test Results

\begin{tabular}{|c|c|c|c|c|}
\hline Variable & Indicator & $\begin{array}{l}\text { Corrected Item- } \\
\text { Total Correlation }\end{array}$ & Cronbach's Alpha & Action \\
\hline \multirow{5}{*}{$\begin{array}{c}\text { Product } \\
\text { Packaging }\end{array}$} & PPD1 & .459 & \multirow{5}{*}{.680} & Continue \\
\hline & PPD2 & .451 & & Continue \\
\hline & PPD3 & .524 & & Continue \\
\hline & PPD4 & .316 & & Revise \\
\hline & PPD5 & .218 & & Revise \\
\hline \multirow{5}{*}{$\begin{array}{l}\text { The Attractiveness } \\
\text { of Advertisement }\end{array}$} & TAD1 & .498 & \multirow{5}{*}{.741} & Continue \\
\hline & TAD2 & .646 & & Continue \\
\hline & TAD3 & .577 & & Continue \\
\hline & TAD4 & .609 & & Continue \\
\hline & TAD5 & .254 & & Revise \\
\hline
\end{tabular}




\begin{tabular}{|c|c|c|c|c|}
\hline \multirow{5}{*}{$\begin{array}{l}\text { Distribution } \\
\text { Intensity }\end{array}$} & Dl1 & .516 & \multirow{5}{*}{.770} & Continue \\
\hline & $\mathrm{Dl} 2$ & .611 & & Continue \\
\hline & Dl3 & .512 & & Continue \\
\hline & $\mathrm{Dl} 4$ & .656 & & Continue \\
\hline & $\mathrm{Dl} 5$ & .497 & & Continue \\
\hline \multirow{5}{*}{$\begin{array}{c}\text { Brand } \\
\text { Awareness }\end{array}$} & BA1 & .425 & \multirow{5}{*}{.723} & Continue \\
\hline & BA2 & .660 & & Continue \\
\hline & BA3 & .320 & & Revise \\
\hline & BA4 & .601 & & Continue \\
\hline & BA5 & .510 & & Continue \\
\hline \multirow{5}{*}{$\begin{array}{l}\text { Purchasing } \\
\text { Intention }\end{array}$} & Pl1 & .403 & \multirow{5}{*}{.834} & Continue \\
\hline & $\mathrm{Pl} 2$ & .765 & & Continue \\
\hline & $\mathrm{Pl} 3$ & .714 & & Continue \\
\hline & $\mathrm{Pl} 4$ & .648 & & Continue \\
\hline & Pl5 & .656 & & Continue \\
\hline
\end{tabular}

Source: Output SPSS 25.0 Processed by Researchers

Table 3 shows the reliability and validity pre-test results. In the initial stage of the study, researcher conducted data collection for the purpose of the pre-test which was done in the first week of November 2018. The researcher distributed questionnaires to 30 respondents who knew and had tried Frisian Flag sweetened condensed milk products that could be used as respondents for this study. The researcher conducted a pre-test to find out whether the charging instructions, construct questions and other important parts of the questionnaire can be understood and indeed accurately represent each variable tested. The pre-test was also used to reduce the potential problems arising from the initial data collected by using SPSS 25.0 software to test reliability and validity, the results of which will be used to evaluate the research questionnaire and then distribute it back to the field.

Reliability and Validity testing were done by looking at the values of Cronbach's Alpha for each variable and Corrected Item-Total Correlation generated from each question. According to Malhotra (2013) the result of Cronbach's Alpha should above 0.68 . While the value of Corrected Item-Total Correlation from each question that is generated should above 0.36 . The Cronbach's Alpha coefficient and Corrected Item-Total Correlation values are obtained by running the SPSS 25.0 program.
Based on Table 3 above, we can see that in the validity test there were several observed variables that were invalid in the construct of Product Packaging, namely PPD4 and PPD5 which had Corrected Item-Total Correlation values less than 0.36 which were 0.316 and 0.218 . Then, the other variable observed was invalid in the construct of the attractiveness of advertisement, namely TAD5, which had a total Item Corrected value of less than 0.36 which was 0.254 . Then other observed variable was invalid in the brand awareness construct, BA3, which had a Total Item Corrected value of less than 0.36 which was 0.320 .

\section{RESULTS AND DISCUSSION Profile of Respondents}

In this study, the researcher included Gender, Age, Current Education, and whether to know Frisian Flag sweetened condensed milk products to the profile of the respondents. If the respondent did not know the Frisian Flag sweetened condensed milk product, the respondent had the right to not continue filling out the survey. The profile of this respondent was adjusted according to the research conducted.

Table 4. Profile Respondents

\begin{tabular}{cccc}
\hline Category & Sub Category & Frequency & Presents \\
\hline \multirow{2}{*}{ Gender } & Female & 47 & $23.5 \%$ \\
& Male & 153 & $76.5 \%$ \\
Age & $15-24$ & 195 & $97.5 \%$
\end{tabular}




\begin{tabular}{cccc} 
& $25-34$ & 2 & $1 \%$ \\
\multirow{4}{*}{ Education } & $35-44$ & 3 & $1.5 \%$ \\
& $>44$ & - & - \\
& Senior High School & 85 & $42.5 \%$ \\
& Bachelor & 111 & $55.5 \%$ \\
& Master & 4 & $2 \%$ \\
\hline
\end{tabular}

Source: Output SPSS 25.0 Processed by Researcher

\section{Convergent Validity}

\begin{tabular}{cccccc}
\multicolumn{5}{c}{ Table 5. Standardized Loading Factor } \\
\hline Variable & Indicator & SLF & Error & $\begin{array}{c}\text { Construct } \\
\text { Reliability }\end{array}$ & $\begin{array}{c}\text { Variance } \\
\text { Extracted }\end{array}$ \\
\hline Product & PPD1 & 0.60 & 0.62 & & \\
Packaging & PPD2 & 0.79 & 0.38 & 0.79 & 0.56 \\
& PPD3 & 0.84 & 0.30 & & \\
\hline Attractiveness & TAA1 & 0.61 & 0.62 & & \\
of & TAA2 & 0.75 & 0.52 & 0.73 & 0.50 \\
Advertisement & TAA4 & 0.77 & 0.41 & & \\
\hline \multirow{2}{*}{ Brand } & DI1 & 0.80 & 0.43 & & \\
Awareness & DI2 & 0.84 & 0.37 & 0.79 & 0.60 \\
& DI5 & 0.68 & 0.49 & & \\
\hline \multirow{2}{*}{ Brand } & BA2 & 0.61 & 0.63 & & \\
Awareness & BA4 & 0.75 & 0.56 & 0.72 & 0.50 \\
& BA5 & 0.77 & 0.41 & & \\
\hline \multirow{2}{*}{$\begin{array}{c}\text { Purchasing } \\
\text { Intention }\end{array}$} & PI1 & 0.71 & 0.66 & & \\
& PI2 & 0.83 & 0.51 & 0.83 & 0.62 \\
& PI3 & 0.79 & 0.71 & & \\
& PI4 & 0.80 & 0.80 & & \\
& PI5 & 0.82 & 0.50 & & \\
\hline
\end{tabular}

Source: Output SPSS 25.0 Processed by Researcher

Hair (2010) suggested the standardized loading factor of the variables observed in the model that met good standards is, if the value of standardized loading factor is $\geq 0.50$. If the standardized loading factor is below than 0.50 , the variable indicator has to be removed. The reliability and validity of this research were done by calculating the construct reliability and variance extracted from the values of standardized loading factors and error variance. According to Sabri (2016), the reliability of the model is good if the Construct Reliability $\geq 0.60$ and validity of the model is good if the Variance Extracted is $\geq 0.50$.

\section{Goodness of Fit Measurement Models}

The Goodness of Fit is done by checking whether the values of Chi-Square and p-value, RMSEA, Standardized RMR, GFI, AGFI, NFI, NNFI, CFI, IFI, RFI which are located in the output meet various sizes that indicate a good match or not.

Table 6. Goodness of Fit Measurement Models

\begin{tabular}{cccc}
\hline Indicator & $\begin{array}{c}\text { Standard Value } \\
\text { for Good Fit }\end{array}$ & $\begin{array}{c}\text { Analysis } \\
\text { Result }\end{array}$ & $\begin{array}{c}\text { Model } \\
\text { Evaluation }\end{array}$ \\
\hline P-value & $\geq 0.05$ & 0.0 & Marginal Fit \\
$R M S E A$ & $\leq 0.08$ & 0.000 & Good Fit \\
NFI & $\geq 0.90$ & 0.92 & Good Fit \\
NNFI & $\geq 0.90$ & 0.94 & Good Fit \\
CFI & $\geq 0.90$ & 0.95 & Good Fit \\
$I F I$ & $\geq 0.90$ & 0.95 & Good Fit \\
$R F I$ & $\geq 0.90$ & 0.90 & Good Fit \\
SRMR & $\leq 0.05$ & 0.092 & Marginal Fit \\
$G F I$ & $\geq 0.90$ & 0.82 & Good Fit \\
$A G F I$ & $\leq 0.90$ & 0.78 & Good Fit \\
\hline
\end{tabular}

Source: Output SPSS 25.0 Processed by Researcher

\section{Analysis of Causal Relations T-value}

From the structural model that researcher obtained from the LISREL output, the result will show the influence of one latent variable with the other latent variables by looking at the value of $t$ ( $t$-value). When $t$-value $\geq 1.96$, the latent variable gives a significant effect on other latent variables. Conversely, when $\mathrm{t}$-value $\leq 1.96$, the latent variable does not have a significant effect on other latent variables.

The use of $\mathrm{R}^{2}$ or coefficient of determination, serves to show how far each variable is able to explain dependent variable (Saidani and Arifin, 2012). According to Makhriyani (2012), the coefficient of determination in structural equations does not have a clear interpretation and to interpret $R^{2}$ as in the regression equation, we must take it from reduced form equations. Based on the reduced form equations of LISREL output, we can see the value of $R^{2}$ for each equation with the analysis as follows:

1. The effect of Product Packaging, The Attractiveness of Advertisement, Distribution Intensity on Brand Awareness has an $\mathrm{R}^{2}$ of 0.65 This shows that $65 \%$ of the Brand Awareness variants can be explained by Product Packaging, The Attractiveness of Advertisement, Distribution Intensity, while $35 \%$ of the other variants are explained by other factors that not discussed in this study.

2. The effect of Brand awareness to Purchasing Intention has $\mathrm{R}^{2}$ of 0.46 . This shows that $46 \%$ 
of the variants of Purchasing Intention can be explained by Brand awareness, while $54 \%$ of the other variants are explained by other factors that not discussed in this study.

\section{Hypothesis Analysis}

In this study there were four hypotheses. Hypothesis testing analysis was carried out with a $5 \%$ significance level to produce a crisis value $t \pm 1.96$. The hypothesis was accepted if the $t$-value obtained was $\geq 1.96$, while the hypothesis was not supported if the t-value obtained was $\leq 1.96$. The following table was a summary of the hypothesis test to see if the proposed model was supported by data:

Table 7. Hypothesis Analysis

\begin{tabular}{|c|c|c|}
\hline Hypothesis & T-Value & Test Results \\
\hline $\begin{array}{l}\mathrm{H}_{1}: \text { Product Packaging } \\
\text { significantly influence } \\
\text { Brand Awareness }\end{array}$ & 1.73 & $\begin{array}{l}\text { Data does not support } \\
\text { the hypothesis }\end{array}$ \\
\hline $\begin{aligned} & \mathrm{H}_{2}: \text { The attractiveness of } \\
& \text { advertisement } \\
& \text { significantly influences } \\
& \text { Brand awareness }\end{aligned}$ & 2.94 & $\begin{array}{l}\text { Data supports the } \\
\text { hypothesis }\end{array}$ \\
\hline 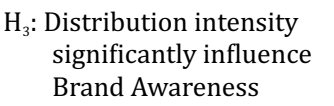 & 4.29 & $\begin{array}{l}\text { Data supports the } \\
\text { hypothesis }\end{array}$ \\
\hline $\begin{array}{l}\mathrm{H}_{4}: \text { Brand awareness } \\
\text { significantly influence } \\
\text { purchasing intention }\end{array}$ & 5.87 & $\begin{array}{l}\text { Data supports the } \\
\text { hypothesis }\end{array}$ \\
\hline
\end{tabular}

Based on Table 7 above which concludes the results of the research model hypothesis, the following points can be explained:
$\mathbf{H}_{\mathbf{1}}$ : Product packaging positively influence brand awareness

Based on the results of processing the data above, the analysis result did not support the hypothesis. This can be seen in Table 9 testing hypotheses, the t-value is only 1.73 so it does not comply with the statistical requirements determined by the t-value must be $\geq 1.96$. In testing this hypothesis, it was found that product packaging of Frisian Flag sweetened condensed milk did not affect customer awareness to brand of Frisian Flag sweetened condensed milk. Researcher suspected that the uniqueness of packaging, the usefulness of packaging, the efficiency of packaging and various packaging variants were not enough to make customers aware to brand of Frisian Flag sweetened condensed milk. The results of this study were different from previous study by Hufron (2015) who said that product packaging has a positive effect on brand awareness. However, the results showed that products packaging of Frisian Flag sweetened condensed milk had no effect on the Brand Awareness. Moreover, the results of this study supported by previous research conducted by Rosandi (2014) which stated that product packaging does not have a positive and significant effect on brand awareness, where the research was conducted in millennials. The price and attractiveness of advertising had a greater influence on brand awareness than product packaging. The researcher concluded that product

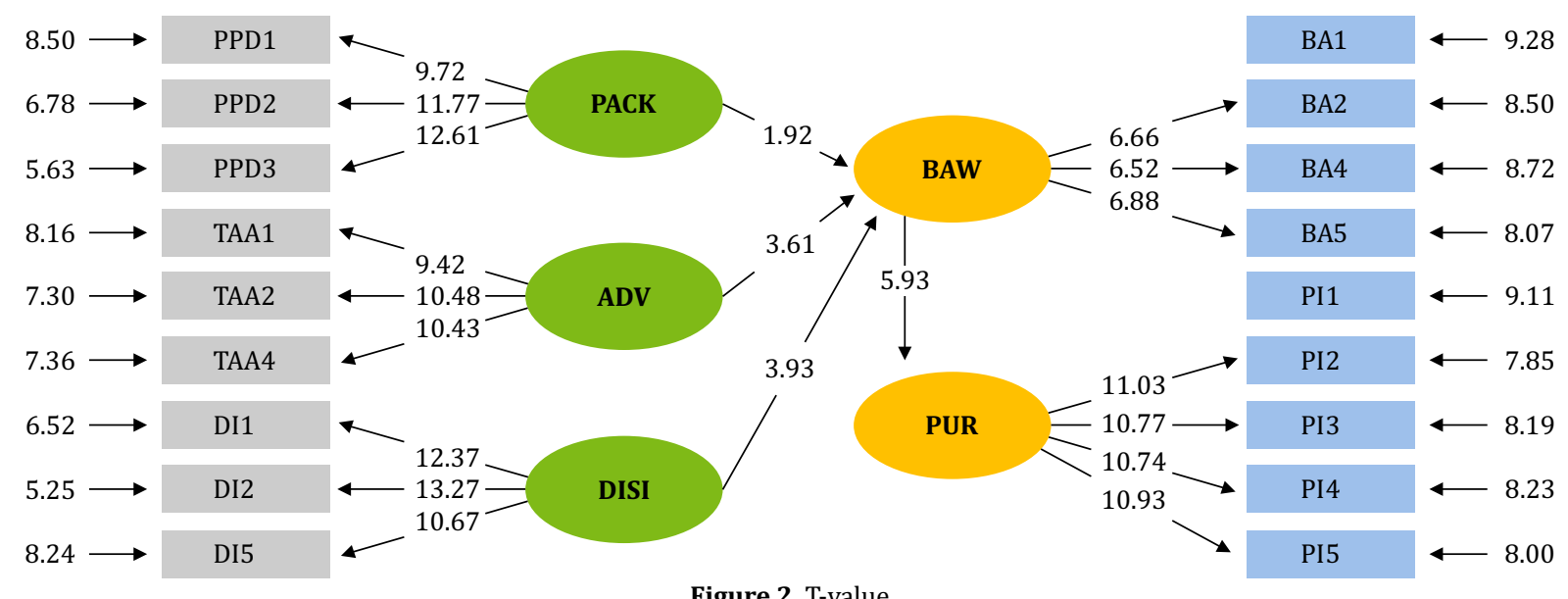

Figure 2. T-value 
packaging did not have a positive and significant effect on brand awareness because $97.5 \%$ of respondents were 15-24 years old.

$\mathbf{H}_{2}$ : The attractiveness of advertisement positively influences brand awareness

Based on the results of data processing in table 9, the research supported the hypothesis. This can be seen in table 9 testing the hypothesis, t-value $\geq 1.96$ which is 2.94 . The result fulfilled the statistic requirements that have been determined. In analyzing this hypothesis, it was founded that the attractiveness of advertisement Frisian Flag sweetened condensed milk positively influence brand awareness of Frisian Flag sweetened condensed milk. In addition, the researcher suspected that the results could not be separated from the marketing strategy of Frisian Flag sweetened condensed milk which contained the uniqueness of ad storyboard, the uniqueness of ad jingle, the uniqueness of ad slogan, the uniqueness of ad message, and the uniqueness script of Frisian Flag sweetened condensed milk ad. Furthermore, this is what made attractiveness of advertisement was possible to be the main factor that influenced consumer's awareness to Frisian Flag sweetened condensed milk. Supported by previous research by Subekti (2010) which stated that the attractiveness of advertising has a positive effect on brand awareness. Moreover, the statement further strengthens that the attractiveness of advertising a product contributes greatly to the process of building brand awareness. The result of this hypothesis analysist also supported by previous research by Muharam (2011) founded that advertising messages, advertising slogans, jingles, pictures and colors are equally influential positive towards brand awareness.

$\mathbf{H}_{3}$ : Distribution intensity positively influence brand awareness

Based on the results of processing the data in table 9, distribution intensity had a positive effect on brand awareness. This can be seen in table 9 testing hypotheses, $\mathrm{t}$-value $\geq 1.96$ which is 4.29 which fulfilled the statistical requirements determined so that hypothesis 3 is supported by data. In testing this hypothesis, it was found that distribution intensity was able to form the awareness of customers of Frisian Flag sweetened condensed milk. The researcher suspected that this happened because the availability of products and the ease of obtaining products in various stores were able to increase customer awareness of the Frisian Flag brand. This was supported by previous research by Riyanto (2015) which stated that distribution has a positive and significant effect on brand awareness. Therefore, it can be concluded that the distribution intensity has a positive effect on brand awareness.

$\mathbf{H}_{4}$ : Brand awareness positively influence purchasing intention

Based on the results of processing the data above, brand awareness also had a positive effect on purchasing intention. This can be seen in table 9 testing hypotheses, $\mathrm{t}$-value $\geq 1.97$ which is equal to 5.87 has fulfilled the statistical requirements specified so that hypothesis 4 is stated to support data. In testing the hypothesis 4 it was found that brand awareness has a positive effect o $\mathrm{n}$ purchasing intention. Researcher assumed that this happened because of the desire to buy Frisian Flag sweetened condensed milk, another factor Frisian Flag sweetened condensed milk being the first product that appeared in the customer's mind if asked to choose the Susu Kental Manis product to be purchased. This was also supported by previous research by Yudhiartika (2012) which stated that the brand awareness variable has a positive influence on buying interest variables. Therefore, it can be concluded that brand awareness has a positive effect on purchasing intention.

Based on the results of t-value analysis shows that product packaging does not affect brand awareness where $\geq 1.96$ which is 1.92 . The researcher conducted a separate test product packaging with two variables supporting brand awareness, namely the attractiveness of advertising 


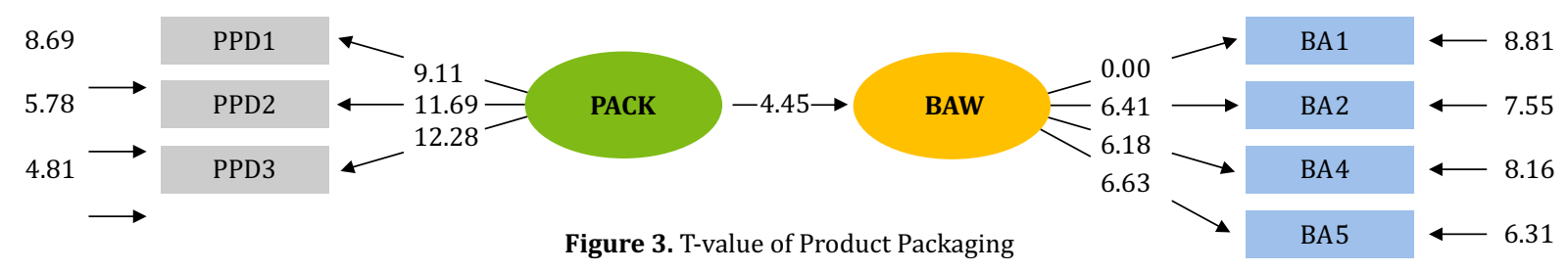

Chi-Square $=32.86, \mathrm{df}=13, \mathrm{p}$-value $=0.00179, \mathrm{RMSEA}=0.085$

Source: Output LISREL 88, Processed by Researcher

and the intensity distribution. However, the researchers found that the results of the analysis of product packaging variables were $\geq$ 1.96 which is 4.45 . This means that product packaging if combined with the attractiveness of advertising and intensity distribution to be examined it turns out that the attractiveness of advertising and intensity distribution will be more dominantly affecting brand awareness compared to product packaging. Product packaging has become a constant or a fixed value for a brand as big as Frisian Flag. If for a new brand, the product packaging deserves attention because customers will assess and remember the brand based on its packaging design. The results of testing variable product packaging toward brand awareness are seen in the figure 3.

\section{CONCLUSION}

From the results of research and discussion it can be concluded from this study that simultaneously the variable attractiveness of advertising and distribution I ntensity has a positive and significant effect on brand awareness. Brand awareness variable has a positive and significant influence on purchasing intention of Frisian Flag sweetened condensed milk. This means that the more the ad can interpret the message properly, the better the customer will recognize the Frisian Flag brand as a top of mind or part of a product. Then, based on the hypothesis analysis states that the better the distribution intensity of a product, the higher the brand awareness that customers feel. Furthermore, according to the results of hypothesis testing states that brand awareness has a positive effect on purchasing intention. It means that the higher the customer awareness of Frisian Flag sweetened condensed milk, the better the intention to buy Frisian Flag sweetened condensed milk. Researcher hope that this research can be a reference for future studies which discuss product packaging, the attractiveness of advertisement, distribution intensity and brand awareness in its influence on purchasing intention.

\section{MANAGERIAL IMPLICATION}

After conducting this research, the future expectations for PT Frisian Flag as the largest shareholder in the "Susu Kental Manis" market in Indonesia is to strengthen the attractiveness of advertising and distribution intensity to increase awareness of the product. In order to improve consumer purchasing intention, researcher recommend to increase the message's attractiveness by designing trustworthy and proven advertising messages. Designing advertising messages that are more exclusive or different from another. Using language that is easily understood by the community for example "slang" languages which is a variety of unofficial and non-standard languages that are seasonal or trendy. In addition, visual animation can also be used to attract advertisements where visual animation can enhance brand awareness from Frisian Flag. The use of virtual animation in advertisements can attract and build brand awareness of millennials, where based on the age of the respondents most of them are millennials. Moreover, Distribution of Frisian Flag sweetened condensed milk can be improved, not only at minimarkets or shops or stalls but also at food event and festival events in the community by opening a stand to sell Frisian Flag sweetened condensed milk or sponsoring the event. According to this idea, Frisian Flag can be found easily because it is available anywhere and anytime. So that the brand's awareness of Frisian Flag will increase. The results of this study can be used as a reference for future researchers to 
Herliani Gemmy, Jony Oktavian Haryanto, Neva Permatasari Sutedjo / Factors Influence Brand Awareness Towards Purchasing Intention on Susu Kental Manis Frisian Flag / 40- 53

develop new research models and consider other variables outside the variables already used in this study, for example, packaging design, intensity distribution, and others.

\section{RE F E RE N C ES}

Elyardi, A. H., \& MAGNADI, R. H. (2014). (Doctoraldissertation, Fakultas Ekonomikadan Bisnis).

Farela, D., \&Darma, G. S. (2014). Celebrity Endorser, Daya Tarik Iklan, Brand Awareness dan Brand Attitude. Jurnal Manajemendan Bisnis, 11(1), 35-47.

Hufron, M. (2015). analisis pengaruh desain kemasan produk dan dayatarik iklan terhadap brand awareness dan dampaknya terhadap minat pembelian pocari sweat. e-jrM, 4(2).

Kumalasari, P., \& SUGIARTO, Y. (2013). analisis pengaruh brand awareness dan brand image terhadap brand equity dan dampaknya pada minat beli konsumen (Studi Kasus Product Placement Mie Instan Indomie Di Dalam Film 5 Cm) (Doctoral dissertation, Fakultas Ekonomika dan Bisnis).

Kusumasari, A. D., \& Supriono, S. (2017). Pengaruh Desain Kemasan Produk dan Daya Tarik Iklan terhadap Brand Awareness Serta Dampaknya pada Keputusan Pembelian Wardah Exclusive Matte Lip Cream (Survei pada Mahasiswi Fakultas Ilmu Administrasi Universitas Brawijaya). Jurnal Administrasi Bisnis, 49(2), 103-111.

Maulana, R. I. (2018). Pengaruh Awareness, Daya Tarik IklanTerhadap Brand Attitude Indomie Kota Tangsel. jurnal pemasaran kompetitif, 1(3).

Malhotra, N. K., Baalbaki, I. B., \&Bechwati, N. N. (2013). Marketing Research. Pearson education ltd.

Makhriyani, ratna A. (2012). Analisis Pengaruh Store Elements Terhadap Repatronage Decision Dengan Dimediasi Oleh Emotional Response Dan Overall Evaluation Pada Restoran Etnis Jawa Mbah Jingkrak. Library Automation and Digital Archive of Universitas Indonesia Library.

Muharam, A. S., \& SOFIAN, S. (2011). Analisis Pengaruh Desain Kemasan Produk dan Daya Tarik Iklan Terhadap Brand Awareness dan Dampaknya Pada Minat Beli Konsumen (Studi Pada Konsumen Susu Kental Manis Frisian Flag di Kota Semarang) (Doctoral dissertation, Universitas Diponegoro).

Octaviasari, S., \& WIDIYANTO, I. (2011). Analisis Pengaruh Daya Tarik Iklan dan Efek Komunitas Terhadap Kesadaran Merekdan Sikap Terhadap Merek Kartu Seluler Prabayar Mentari di Semarang (Doctoral dissertation, Universitas Diponegoro).

Permana, M. S., \& Haryanto, J. O. (2013). Pengaruh Country of origin, Brand Image Dan Persepsi Kualitas Terhadap Intensi Pembelian. Jurnal Manajemen Untar, 18(3).

Purnamasari, I. M. (2016). pengaruh kemasan terbaru susu kental manis "frisian flag" dan daya tarik iklan terhadap minat beli konsumen pada masyarakat semarang (Doctoral dissertation, Fakultas Ilmu Komunikasi UNISSULA).

Qurohman, T. (2016). Pengaruh Kualitas Produk, Daya Tarik Iklan, Dan Persepsi Harga Terhadap Minat Beli Konsumen Handphone Pada Produk Merek Samsung (Studi Kasus Di Kecamatan Kaliwungu Kabupaten Kudus) (Doctoral dissertation, Universitas Muria Kudus).

Ratnawati, W., \& SUHARNOMO, S. (2011). Analisis pengaruh perceived advertising spending dan intensitas distribusi terhadap ekuitas merek (Studi Kasus Merek Khong Guan di Semarang) (Doctoral dissertation, Universitas Diponegoro).

Resmi, N., \& Wismiarsi, T. (2015). Pengaruh Kemasan dan Harga pada Keputusan Pembelian Minuman Isotonik. Jurnal Manajemen dan Bisnis Sriwijaya, 13(1), 1-20.

Rusli, L., \& Sari, T. K. (2013). Analisis Teks Iklan Susu Formula Anak berpengaruh terhadap kesadaran merek. 
Rosandi, S. (2014). Pengaruh Citra Merek dan Desain Kemasan terhadap Minat Beli Konsumen pada Produk Susu Ultra (Studi pada Café taria Srikandi Fakultas Ekonomi Universitas Negeri Surabaya). Jurnal Pendidikan Tata Niaga (JPTN), 2(2).

Sabri Ahmad, N. N. A. Z., \& Khairu shalimi, F. I. Assessing the Validity and Reliability of a Measurement Model in Structural Equation Modeling (SEM).

Semuel, H., \&Setiawan, K. Y. (2018). Promosi melalui sosial media, brand awareness, purchase intention pada produksusu uht.Jurnal Manajemen Pemasaran, 12(1), 47-52.

Situmeang, I. V. O. (2015). Pengaruh Daya Tarik Iklan Televisi Cosmetik Wardah Terhadap Keputusan Pembelian. Jurnal Komunikasi Pembangunan, 11(2).

Soesatyo, N. (2013). Analisa Credibility Celebrity Endorser Model: Sikap Audience terhadap Iklan dan Merek Serta Pengaruhnya Pada Minat Beli" Top Coffee". Jurnal Strategi Pemasaran, 1(2), 1-12.

Subekti, A. Y., \& DIRGANTARA, I. (2010). Analisis Pengaruh Citra Merek dan Kesadaran Merek Terhadap Ekuitas Merek Susu Cair Dalam Kemasan "Indomilk"(Doctoral dissertation, Universitas Diponegoro).

Yudhiartika, D., \&Haryanto, J. O. (2012). Pengaruh Personal Selling, Display, Promosi Penjualan Terhadap Kesadaran Merek Dan Intensi Membeli Pada Produk Kecantikan Pond's. Buletin Studi Ekonomi.

Triwijanarko, R. (2018, July 09). Marketeers.com. Retrieved from Kementerian Perindustrian Tegaskan Susu Kental Manis Aman Dikonsumsi: http://marketeers.com/susu-kental-manis-aman-dikonsumsi/

Islahuddin. (2017, agustus 10). SURVEI BPS Susu kental manis berjaya di kalangan rumah tangga. Retrieved from beritagar.id: https://beritagar.id/artikel/berita/susu-kental-manis-berjaya-di-semuakalangan-rumah-tangga

Tribun Jabar. id. (2018, agustus 18). Susu Kental Manis Aman Selama Proporsional. Retrieved from Tribun jabar. id: http://jabar.tribunnews.com/2018/08/13/susu-kental-manis-aman-selamaproporsional

Top Brand Index 2017 Fase 1. (2017, JUNI 15). top brand award kategori ; makanan dan minuman.

Retrieved from TOP BRAND: http://www.topbrand-award.com/top-brand-survey/surveyresult/top_brand_index_2017_fase_1 